\title{
THE FIRSTNESS OF THE FIRST AMENDMENT
}

\section{EDMOND GAHN†}

ONE's sympathy goes out to young James Madison in the fall of 1788 . After the strenuous labors of the Constitutional Convention, he had traversed a series of anxious stages on the road to ratification. The state conventions (except in North Carolina and Rhode Island) had ultimately voted approval, but several of them-including his own Virginia-had exacted a promise that amendments would be adopted promptly to declare the people's fundamental liberties. When the initial Congress under the new Constitution convened in the spring: of 1789 , Madison knew, it would be watched with suspicion and distrust until the pledge was redeemed and the amendments submitted to the states. ${ }^{1}$ The enterprise was to be his, as leader in the House of Representatives-to assemble the multifarious state proposals, organize them in rational order and guide them through. He understood that some reassuring action was inevitable: to this he was bound in honor and reconciled in thought. But a vague, general expectation was scarcely enough for a mind as analytical as his. He foresaw that while the Constitution's adversaries might wreck the whole fabric by submitting destructive amendments, the arrogant and intransigent among the federalist group might refuse to consider amendments which were entirely reasonable. To steer through this perilous strait, he must study his course carefully, critically, in advance.

\section{Why Should the Rights be Declared?}

During the previous year, Madison had often exchanged views of the subject with Thomas Jefferson, who was representing the United States in Paris.

$\dagger$ Professor of Law, New York University School of Law.

1. Reflecting the general expectation, President Washington's message to the First Congress, delivered April 30, 1789, contained the following:

"Besides the ordinary objects submitted to your care, it will remain with your judgment to decide how far an exercise of the occasional power delegated by the fifth article of the Constitution, is rendered expedient at the present juncture, by the nature of objections which have been urged against the system, or by the degrec of inquietude which has given birth to them. Instead of undertaking particular recommendations on this subject, in which I could be guided by no lights derived from official opportunities, I shall again give way to my entire confidence in your discernment and pursuit of the public good: for, I assure myself, that whilst you carefully avoid every alteration which might endanger the benefits of a united and effective Government, or which ought to await the future lessons of experience; a reverence for the characteristic rights of freemen, and a regard for the public harmony, will sufficiently influence your deliberations on the question, how far the former can be more impregnably fortified, or the latter be safely and advantageously promoted."

1 Annals of Cong. 28-29 (1789). 
From the first, Jefferson had insisted that "a bill of rights is what the people are entitled to against every government on earth. ..." Now it was fitting to tell him that his demand would be met. Under these circumstances, on October 17, 1788, Madison composed a letter of self-examination and selfrevelation. In it he announced the withdrawal of his early objections ${ }^{3}$ to a declaration of rights, and proceeded to conduct a conscious search for the doctrines and practical criteria he would use to guide his course in the Congress.

Madison still believed-as he had from the beginning of the correspondence - that since the real power in a republic resides in the people, it is they who are the main source of danger to freedom. Solemn declarations still seemed to him like "parchment barriers," for "in Virginia, I have seen the [state] bill of rights violated in every instance where it has been opposed to a popular current." Well, then, was it all to be a pious fraud, which he would only compound by proposing solemn amendments to the forthcoming Congress? No, Madison said, addressing simultaneously his distant friend and his own conscience:
"What use, then, it may be asked can a bill of rights serve in popular Governments? I answer, the two following which, though less essential than in other Governments, sufficiently recommend the precaution: 1 . The political truths declared in that solemn manner acquire by degrees the character of fundamental maxims of free Government, and as they become incorporated with the National sentiment, counteract the impulses of interest and passion. 2. Although it be generally true, as above stated, that the danger of oppression lies in the interested majorities of the people rather than in usurped acts of the Government, yet there may be occasions on which the evil may spring from the latter source; and on such, a bill of rights will be a good ground for an appeal to the sense of the com- munity. Perhaps, too, there may be a certain degree of danger, that a succession of artful and ambitious rulers may by gradual and well-timed advances, finally erect an independent Government on the subversion of liberty. Should this danger exist at all, it is prudent to guard against it, especially when the precaution can do no injury."

2. Letter from Thomas Jefferson to James Madison, December 20, 1787. 6 THE WRITnugs of Thomas Jefrerson 385 (Memorial ed. 1904). Jefferson sent an edited copy of this famous letter to Uriah Forrest on December 31, 1787, with leave to use it "but withwut quoting its author." 5 The Works of ThoMras JefFERson 379 (Federal ed. 1904). For a splendid account of developments leading to adoption of the Bill of Rights, see the third volume of Irving Brant's definitive biography, JAmes MAdison: Father of the Constiturion 1787-1800 (1950), particularly chapter XXI.

3. At Philadelphia and in the ensuing debates, The Federalist had developed a standard list of reasons why a bill of rights did not belong in the new Constitution. Hamilton's arguments in ThE FEDERALIST No. 84 may be taken as representative.

4. Letter from James Madison to Thomas Jefferson, October 17, 1788. 1 LetTers and Other Writings of Jamies Madison 424 (Rives ed. 1865).

5. 1 id. at $426-27$. 
This letter, which was delayed in some strange fashion, ${ }^{6}$ gave Jefferson rather less comfort than the prevailing party may expect in an argument between friends. He seems to have wondered why Madison had paraded so much subtlety to refute a list of obviously false objections. On March 15, 1789, Jefferson replied. Somewhat lightly, he complimented Madison for conceiving bright answers to what he apparently considered very dull questions. He added several summary answers-or rather, retorts-of his own. Here is a sample:

"4. 'Experience proves the inefficacy of a bill of rights.' True. But though it is not absolutely efficacious under all circumstances, it is of great potency always, and rarely inefficacious. A brace the more will often keep up the building which would have fallen, with that brace the less. There is a remarkable difference between the characters of the inconveniences which attend a declaration of rights, and those which attend the want of it. The inconveniences of the declaration are, that it may cramp government in its useful exertions. But the evil of this is shortlived, moderate and reparable. The inconveniences of the want of a declaration are permanent, afflicting and irreparable."7

Not satisfied with merely elaborating Madison's defenses and replies, Jefferson went on to urge what he considered the affirmative side of the case. For the first time in the course of the transatlantic dialogue, he came to assert:

"In the arguments in favor of a declaration of rights, you omit one which has great weight with me; the legal check which it puts into the hands of the judiciary. This is a body, which, if rendered independent and kept strictly to their own department, merits great confidence for their learning and integrity. In fact, what degree of confidence would be too much, for a body composed of such men as Wythe, Blair and Pendleton :s On characters like these, the 'civium ardor prava jubentium' [frenzy of the citizens bidding what is wrong $]^{9}$ would make no impression." 10

Thus Jefferson opened his mind. First, an explicit declaration of rights was indispensable because it would furnish the judiciary with a "legal check" on aggressions against liberty. Second, to perform their function, judges must be "rendered independent." Third, the judges must be kept "strictly to their own department."11 Fourth, good judges would be men of "learning and integrity"

6. Letter from Thomas Jefferson to James Madison, March 15, 1789. 7 The Writings of Thomas JefFerson 309 (Memorial ed. 1904).

7. $7 i d$. at 311. (Inner quotation marks added.)

8. These eminent judges constituted at that time Virginia's High Court of Chancery. See David J. Mays' monumental biography, EDMUNd PENDLETon 1721-1803, vol. 2, at 156 (1952). For information about John Blair on the Supreme Court, see 1 Warren, The SuPRENE Court in United States Hrstory 38, 70-71, 141 (rev. ed. 1932).

9. The quotation is from HoRACE's OdEs, bk. III, ode iii.

10. Letter from Thomas Jefferson to James Madison, March 15, 1789. 7 The WritINGS OF THOMAS JEFFERSON 309 (Memorial ed. 1904).

11. This is an interesting qualification, for in his letter of December 20, 1787, he had expressed a preference for associating the judges in the President's veto power or investing them "separately with a similar power." Letter from Thomas Jefferson to James Madison. 6 id. at 387. 
(like Wythe, Blair and Pendleton), whose characters would stand firm amid the storms of popular passion.

How fortunate for the constitutional dignity and efficacy of the Bill of Rights that Madison was required to wait until June 8,1789 , before addressing the Congress on the subject! By that time, when the House of Representatives at long last turned its attention to the proposed amendments, Jefferson's critically important letter had arrived in New York. ${ }^{12}$

In his principal speech, Madison told the House candidly that he still considered the popular community as the locus of greatest power, hence of greatest danger, in a republic. Nevertheless, he said, even if constitutional guarantees would be only "paper barriers," they might at least enlighten public opinion and inculcate respect for individual rights. ${ }^{13}$ With these mild currents running through it, his speech was bound to be a tepid one. It was one thing to paraphrase Jefferson and quite another to share his felt convictions. ${ }^{14}$ Madison sounded conciliatory, reasonable, and rather detached. He seemed to doubt that even a limited protection could be devised against the people's unreasoning heat and violence. While it was quite intelligent of him to suggest that constitutional guarantees might serve as educational precepts for the community, he apparently failed to recognize that the precepts would be driven home only if court decisions would enforce them. For if the guarantees were destined to be ignored in court, they would become very ineffectual pedagogues of republican ideals; worse yet, they would provoke mockery and cynicism. At bottom, I think Madison tended during this period of his development to underestimate-as Jefferson did not-the profound adverseness of interest between

12. According to Mr. Brant, "All of Jefferson's private letters came by diplomatic pouch, and a dispatch of March 15 to Foreign Secretary Jay was received on June 2." Letter from Irving Brant to Edmond Cahn, October 18, 1955. I follow Mr. Brant in attributing this part of Madison's presentation to Jefferson's letter to him of March 15, 1789. See 3 Brant, op. cit. supra note 2, at 267.

13. 1 Annals of Cong. 455 (1789).

14. A week later, on June 17,1789 , in the extended debate on the President's power to remove appointive officers without legislative concurrence, Madison said:

"It is therefore a fair question, whether this great point may not as well be decided, at least by the whole Legislature as by a part, by us as well as by the Executive or Judiciary? As I think it will be equally constitutional, I cannot imagine it will be less safe, that the exposition should issue from the legislative authority than any other; and the more so, because it involves in the decision the opinions of both those departments, whose powers are supposed to be affected by it. Besides, I do not see in what way this question could come before the judges, to obtain a fair and solemn decision; but even if it were the case that it could, I should suppose, at least while the Government is not led by passion, disturbed by faction, or deceived by any discolored medium of sight, but while there is a desire to all to see and be guided by the benignant ray of truth, that the decision may be made with the most advantage by the Legislature itself."

1 id. at 520-21. This presents an unintended but nonetheless excellent summary of the ruasons for referring justiciable constitutional issues to the judges at all times after June, 1789. 
the governors and the governed in any political society (except only the direct, participating self-government of a town meeting).

Nevertheless, in presenting the proposed amendments to Congress, Madison did declare the momentous doctrine he had derived from Jefferson's letter. Not having assimilated it entirely, he expressed it on this occasion with a mechanical absoluteness which was not characteristic of him. He mentioned no qualifications. The First Congress was frankly and explicitly informed that the sponsors of the Bill of Rights expected the judges to "consider themselves in a peculiar manner the guardians of those rights."15 Madison told the House:

"If they [the rights] are incorporated into the constitution, independent tribunals of justice will consider themselves in a peculiar manner the guardians of those rights; they will be an impenetrable bulwark against every assumption of power in the legislative or executive; they will be naturally led to resist every encroachment upon rights expressly stipulated for in the constitution by the declaration of rights."16

\section{A Curious Debate: Should There Be a Bill of Rights?}

At this stage, one might expect that chance, having postponed Madison's principal address until Jefferson's letter arrived, had fulfilled its role and would withdraw from the narrative. But there was another unpredictable happening ahead, which would have momentous consequences in constitutional law. The episode was as brief as it was strange.

In view of the novelty of the amendment provisions in Article $V$ of the Constitution, Madison may well have entertained doubts as to the proper mode of proceeding. ${ }^{17}$ Nevertheless, by June 8th when he addressed the Congress, he had a definite method to propose: The way to amend the Constitution was to insert new matter in the appropriate places of the existing text and simply replace old words and phrases with the new words and phrases that would supersede them. People had been complaining that certain safeguards should have been included in the Philadelphia document; very well, let that be done now by incorporating the provisions where it was claimed they had belonged from the start. This was Madison's interpretation of the amending procedure contemplated under Article V.

In the episode Madison's chief adversary was to be old Roger Sherman, experienced, skillful, "as cunning as the Devil."18 On June 8, 1789, Judge Sherman was satisfied to take the floor briefly and express his general opposition to a bill of rights. He saw no need for one : moreover, only time and ex-

15. 1 id. at 457 .

16. Ibid.

17. As late as May 27th, 1789, there was still a note of uncertainty on this score. Madison wrote Jefferson on that day, "A Bill of rights, incorporated, perhaps, into the Constitution, will be proposed. ..." 1 LetTers and Other Writings of JaMres Madison 473 (Rives ed. 1865).

18. The phrase was Jeremiah Wadsworth's. 17 Dictionary of AmirRican Biography 90 (Malone ed. 1935). 
perience would show what specific amendments were desirable. Since Connecticut, his state, had not insisted on a bill of rights as a condition to ratifying the Constitution, Sherman's position was entirely comfortable. He let matters talse their course until August 13th, when the committee appointed in June to consider proposed amendments brought in its report.

At this juncture, Sherman rose to insist "We ought not to interweave our propositions into the work itself, because it will be destructive of the whole fabric"; and he moved that all amendments be made by way of addition and supplement to the existing constitutional text. ${ }^{10}$ The motion precipitated a long and intricate debate. Madison's chief interest was in avoiding further delay; the difference between the two procedures, he insisted, was only a matter of form; Sherman's motion would "so far unhinge the business, as to occasion alterations in every article and clause of the report."20 Some very penetrating arguments having been exchanged, Sherman's motion was voted on and defeated. Apparently this setback did not dismay the old judge, who knew well that the first vote is not always the decisive one. When on August 19th the House again considered the amendments as a committee of the whole, Sherman renewed his motion. After what amounted to a repetition of the earlier debate, the motion was carried by two-thirds of the House. ${ }^{21}$ Madison acquiesced, and the Sherman procedure became a permanently established constitutional practice.

In certain respects, the episode could hardly have been more paradoxical. Had it not been for Roger Sherman's insistence, our basic guarantees would have been sprayed over the constitutional text instead of being assembled in a single, integrated bill of rights. One would think it fairly apparent that a declaration of rights could exert greater educational influence on the general population if it was adopted in a unitary and consecutive form. Yet Madison, expounder of the importance of community opinion and the educational value of written guarantees, did not perceive this at all. On the opposite side, we find equal incongruity. Roger Sherman, who declared himself opposed to the libertarian amendments, nevertheless recommended-and achieved-the very amendatory procedure best suited to invest them with life and force. I suggest that, in Sherman's case, it was the pull of professional experience and craftsmanship that overcame competing motivations. He seems to have reasoned, in effect, that if the laymen were resolved to have their written guarantees, the lawyers must at least show them the proper and artificial way to go about it. As we know, the assembling of the guarantees in a unified Bill did considerably more than increase their educational value. In constitutional law, the impact of Roger Sherman's motion was to prove momentous and permanent. It introduced a new factor in the theory of civil liberties, for it conferred contextuality on the first ten amendments.

19. 1 Annals of Cong. 734-35 (1789).

20. 1 id. at 740 .

21. 1 id. at 795 . 
This attribute of contextuality has influenced whole areas of later constitutional doctrine. Consider, for example, the long period during which the Supreme Court used the Tenth Amendment as the avenue of approach to other portions of the Bill of Rights. (Under Madison's proposal, the basic guarantees would have been tucked away in sections 6,9 and 10 of Article I and section 2 of Article III; and what was to become the Tenth Amendment would have stood far away from them in an Article VII.) ${ }^{22}$ Again, consider the decisions of the most recent years, those of the decade since World War II. In several of these, the specific prohibitions of the Bill of Rights have been treated as though they were mere adjuncts to the Due Process Clause's overall requirement of reasonableness. Whether it was the arm of destiny or the finger of partisanship or only the impulse of professional competence that prevailed in Congress along with Roger Sherman, the forces he set moving in the summer of 1789 are more active and prominent today than ever. The laissea faire jurists of our time choose the Due Process Clause as their habitual perspective position, while the libertarian jurists usually prefer a much firmer point of vantage; nevertheless, both groups follow the practice of construing the first ten amendments as a unified, organic text. That is how, within the framework of the Bill of Rights, it has become possible to speak of the functional "firstness" of this or that particular amendment.

\section{May the Rights Be Graded?}

Point by point, we have so far identified historical archetypes for articles in the libertarian creed of our own time: (a) the declaration of explicit constitutional guarantees, (b) the reliance on judges for enforcement within the orbit of their competence, and (c) the adherence to a unified Bill of Rights. Except for one important element, our picture shows that a libertarian jurist of the present day-for example, Justice Hugo L. Black-may claim continuity with the original republican tradition. A critical element, however, remains for testing. The question is: Are there also eighteenth century precedents to sanction modern libertarians in grading the respective guarantees?

Here we have the central battleground where current philosophies meet and clash. If a judge responds to the contextuality of the Bill of Rights by reading the whole Bill in terms of the Due Process Clause, he may construe other clauses, which contain absolute prohibitions, as though they merely specified and illustrated an over-all criterion of reasonableness; and he may go much farther. His approach will prompt him to conclude that that is reasonable which the legislature has, by enacting it, found to be reasonable. Of course, this conclusion is not at all incompatible with bewailing what, in a particular instance, the legislature has seen fit to do; judicial opinions of the laissez faire school are often accompanied by hand-wringing, some of which is quite sincere. But the result is nonetheless to make the texture of First Amendment rights look just as porous as the Due Process Clause.

22. 1 id. at $451-53$. 
For several years past, Justice Black has struggled resolutely against the laissez faire trend. ${ }^{23}$ Like other libertarian judges, he believes the Constitution confers a "preferred position" on certain guaranteed rights as against others. When governmental action restricts freedom of religion, or speech, or the press, or assembly, he refuses to let it pour at will through the wide meshes of due process. He too has been affected by the contextuality of the Bill of Rights, but with results very different from those of the laissez faire school. Since his attitude toward personal liberty is formed by the flat prohibitory language of the First Amendment, he approaches even the subordinate provisions of other amendments in a stiffer mood. For example, in Justice Black's axiology, the privilege against self-incrimination, instead of being linked to the Due Process Clause, its Fifth Amendment neighbor, is valued as a defense and practical implement for First Amendment freedoms. The whole philosophy rests on assigning the various guarantees to distinct classes and grades. Does the tradition furnish any precedent for this process of grading?

Before attempting an answer, it would be advisable to pause for a moment and take counsel. Suppose the answer should be affirmative. Suppose we should find some clear and persuasive eighteenth century precedents. Would that circumstance control the Court's jurisprudence today, over a century and a half later? I should say, assuredly not. I do not think the American people unseated George III with a view to putting history in his place. The Bill of Rights is a national inheritance precisely because it has passed again and again from the dead to the living - to be used as the living find best, re-interpreted in the using, then passed along to the succeeding generation. To agree with what Jefferson and Madison may have intended or may have communicated to the Congress is only a comfort, not an obligation. If, in the considered judgment of our time, the process of grading the rights is found to fill the immediate and the long-term needs of civil freedom, we certainly ought to grade them, whatever the eighteenth century would have done.

But to say these things does not amount to dismissing the past. If a libertarian ought not to brandish the history of the Bill of Rights like a sword or recline on it like a couch, he may at least present it before him like a shield. If he should be charged with inventing a new constitutional doctrine, he may properly show that he is only maintaining a very old one; and even if he should be convicted of deviating from Brandeis, he may still make bold to submit that he is returning to Jefferson. Laissez faire jurists have assigned historical arguments, among others, for treating all the rights as though they had a uniform texture. The idea of grading, they contend, ought to be abandoned because it is a recent innovation in the theory of civil liberties. By way of comment on the argument, it is worthwhile to look at three quick tableaux.

First Tableau. The year is 1787 or 1788 ; the place is Paris. Thomas Paine has just returned to his quarters after a long talk with Jefferson. Too excited to rest, he sits down and writes:

23. Beatharnais v. Illinois, 343 U.S. 250, 268-70, 274-75 (1952) (dissenting opinion); Breard v. Alexandria, 341 U.S. 622, 650 (1951) (same); Dennis v. United States, 341 U.S. 494, 580 (1951) (same). 
"After I got home, being alone and wanting amusement I sat down to explain to myself (for there is such a thing) my Ideals of natural and civil rights and the distinction between them-I send them to you to see how nearly we agree.

"Suppose 20 persons, strangers to each other, to meet in a country" not before inhabited. Each would be a sovereign in his own natural right. His will would be his Law, - but his power, in many cases, inadequate to his right, and the consequence would be that each might be exposed, not only to each other but to the other nineteen.

"It would then occur to them that their condition would be much improved, if a way could be devised to exchange that quantity of danger into so much protection, so that each individual should possess the strength of the whole number. As all their rights, in the first case, are natural rights, and the exercise of those rights supported only by their own natural individual power, they would begin by distinguishing between these rights they could individually exercise fully and perfectly and those they could not.

"Of the first kind are the rights of thinking, speaking, forming and giving opinions, and perhaps all those which can be fully exercised by the individual without the aid of exterior assistance-or in other words, rights of personal competency-Of the second kind are those of personal protection of acquiring and possessing property, in the exercise of which the individual natural power is less than the natural right.

"Having drawn this line they agree to retain individually the first Class of Rights or those of personal Competency; and to detach from their. personal possession the second Class, or those of defective power and to accept in lieu thereof a right to the whole power produced by a condensation of all the parts. These I conceive to be civil rights or rights of Compact, and are distinguishable from Natural rights, because in the one we act wholly in our own person, in the other we agree not to do so, but act under the guarantee of society." 24

The notions Paine expressed were not nearly so novel as he imagined. I should suggest that it was John Locke who transmitted the pattern-not in his Second Treatise of Civil Government, where scholars have searched in vain for any grading of basic rights, but in his Essay Conccrning Human Understanding. In the latter, Locke (who may have been prompted in turn by Robert Boyle, the eminent chemist and philosopher of nature) had supplied a model of physical and metaphysical classification which his eighteenth century American admirers could easily adopt and use for their political theories. According to Locke the qualities of any body are either "primary," like solidity, extension, figure and mobility, which "are utterly inseparable from the body, in what estate soever it be"; or "secondary," like colors, sounds and tastes, which are only "powers to produce various sensations in us by their primary qualities." 25 For the educated men of the Enlightenment, it would be

24. G. Chinard, Thodias Jefrerson: The Apostle of Americanism $\$ 0-81$ (2d ed., rev. ed. 1948).

25. Locke, Essay Concerning Hunin Understanding, bk. II, c. ViII. See alsr id., bk. II, c. XXX; bk. IV, c. III; bk. IV, c. VI. Later criticism has refuted the pattern 
a short leap from Locke's grade of "primary" and "inseparable" qualities to Paine's corresponding "natural rights of personal competency"; or from Locke's grade of "secondary" and affective qualities to Paine's corresponding "rights of compact" which arise in civil society. One need only change "any body" in Locke's text to "anybody," and the rest of the pattern emerges.

Second Tableau. We are back in New York on June 8, 1789, where Madison is expounding the Bill of Rights to the House of Representatives. Far from considering the rights all of one piece, grade and texture, he classifies and re-classifies them like a virtuoso of the taxonomic art. First, he classifies the rights in order to distinguish the American problem from the English experience with Magna Charta. Magna Charta, he says, furnishes no answer because it "does not contain any one provision for the security of those rights, respecting which the people of America are most alarmed." 26 He refers here to "the freedom of the press and rights of conscience" as "those choicest privileges of the people."27

Then he re-classifies the various rights in terms of their origins. If one analyzes bills of rights, one will find:

"In some instances they assert those rights which are exercised by the people in forming and establishing a plan of Government. In other instances, they specify those rights which are retained when particular powers are given up to be exercised by the Legislature. In other instances, they specify positive rights, which may seem to result from the nature of the compact. Trial by jury cannot be considered as a natural right, but a right resulting from a social compact which regulates the action of the community, but is as essential to secure the liberty of the people as any one of the pre-existent rights of nature."28

A few minutes later, he proposes still another order for grading the rights. Some guarantees are asserted against the executive, others against the legislative branch; some against the federal government as a whole, others against the state governments. Since however the greatest danger, as he believed, lay in the democratic community, the "prescriptions in favor of liberty ought to be levelled in that quarter." 29 This third method of classifying, based on the -ources and directions from which civil liberties may be menaced, is probably more representative of Madison's personal thinking than the other two. Yet, in his judgment, the result would not vary: the freedoms embodied in the First Amendment must always secure paramountcy. ${ }^{30}$

for physical, metaphysical and epistemological purposes, but its utility as a political paradigm may remain unimpaired.

26. 1 Annals of Cong. 453 (1789).

27. Ibid.

28. 1 id. at 454 .

29. Ibid.

30. In Mr. Brant's view, Madison's original resistance to a bill of rights was due to his apprehension "that limitations of language and public opinion might render the basic freedom, that of religion, too narrow for security. If it were infringed, prejudice and 
Third Tableau. A year and a half later. Having assumed the office of Secretary of State, Jefferson is now in Philadelphia. From Hartford, Noah Webster has sent copies of his Essays, one for the Secretary of State to file for copyright protection, one for Jefferson to add to his personal library. On reading the Essays, which are dated "New York 1788," Jefferson finds that Webster has taken him to task for advocating the adoption of a bill of rights. On December 4th, 1790, in a letter replete with tact and thoughtfulness, Jefferson writes:

"A desire of being set right in your opinion, which I respect too much not to entertain that desire, induces me to hazard to you the following observations. It had become an universal and almost uncontroverted position in the several States, that the purposes of society do not require a surrender of all our rights to our ordinary governors; that there are certain portions of right not necessary to enable them to carry on an effective government, and which experience has nevertheless proved they will be constantly encroaching on, if submitted to them; that there are also certain fences which experience has proved peculiarly efficacious against wrong, and rarely obstructive of right, which yet the governing powers have ever shown a disposition to weaken and remove. Of the first lind, for instance, is freedom of religion; of the second, trial by jury, habeas corpus laws, free presses. These were the settled opinions of all the States, -of that of Virginia, of which I was writing, as well as of the others."3i

He went on to call the first class "unceded portions of right" and the second class "fences against wrong." 32

In classifying freedom of the press along with other "fences against wrong," it is not likely that Jefferson intended to derogate from the press's station and dignity as a means of free personal expression. In any case, we need not inquire now whether Jefferson's mode of grading was valid in 1790. For our purposes, it is enough to record that like others of his era he did grade the various guarantees and that, in grading them, he awarded primacy to the freedoms of conscience and personal expression.

Thus the judicial libertarianism of the American present is securely linked with a very old and genuine tradition. In insisting on the firstness of the First Amendment, modern thinkers like Hugo Black are continuing and advancing the American vision of a good society. Popular majorities being what they often are and acting as they often do, the libertarian tradition requires an extraordinarily patient, if not obstinate, fortitude. Recently Justice Black summarized the credo: "In my judgment, the very heart of the Bill of Rights is the First Amendment. Unless people can freely exercise those liberties, with-

intolerance would tear down everything else." Mr. Brant concludes, "Charged with the task of drawing a bill of rights, the very apprehensions which made him hesitate spurred him to superlative performance." 3 Brant, James Madison: Father of the ConstituTXON 275 (1950).

31. Letter from Thomas Jefferson to Noah Webster, December 4, 1790. 8 ThE WRITings of Thonas JefFerson 112 (Memorial ed. 1904).

32. Ibid. 
out loss of good name, job, property, liberty or life, a good society cannot exist. That is my faith." 33

\section{The Aniendnent in Black Letter, Writ Large}

It is time now to consider Hugo Black's personal contribution. Has he given anything of his own to the tradition; in what respects, if any, has he moved it forward? Before attempting to list the answers, let us first summon his sense of humor and native clemency, for if we are about to misread or misconstrue his thinking, only the former will console him and only the latter will rescue us. With these our guardians, we proceed to epitomize.

Emphasis on Text and Texture. Not very many years ago, it was modish in sophisticated liberal circles to insist that the Court ought to apply the literal text of the Constitution, as distinguished from various judge-made phrases, concepts and glosses. Only by adhering to the text, liberals were wont to argue, could the Court reconcile its own power of judicial review with the democratic postulate of majority rule; only thus could it exercise the self-discipline needed for wise adjudication. No one has taken these once-popular admonitions more seriously than Hugo Black. To him the language of the Constitution is more than a source of law, it is the only authentic commission of his office. Hence, when he comes to consider the Bill of Rights, he insists that the Court pay due regard to differences of tenor and mood in the several provisions-in short, that contextuality must not prevail to the extent of eliminating textuality.

On this reasoning, none of the schemes we have mentioned for classifying and grading the guarantees would quite suit his purpose. He would be inclined to prefer a more textual criterion for grading. And he has found one in Madison's famous phrase, likewise in the speech of June 8, 1789, distinguishing fields "in which the Government ought not to act" from fields in which it ought "to act only in a particular mode."34 According to Justice Black, the language of the First Amendment belongs unmistakably to the former category: it tells the authorities not to act at all. By way of contrast, the prohibition of "unreasonable" searches (Fourth Amendment) and the Due Process Clause (Fifth Amendment) contemplate that the authorities may act if only they act reasonably. To exclude absolutely is one thing; to admit yet require reasonableness is another.

Against these views of Justice Black's, it has been objected that the First Amendment's guarantee of free expression has never been taken so literally as to grant immunity from civil liability for libel or slander. If there are con-

33. Commencement Address by Justice Black at Swarthmore College, June 6, 1955.

34. Madison said, "But whatever may be the form which the several States have adopted in making declarations in favor of particular rights, the great object in view is to limit the powers of Government, by excepting out of the grant of power those cases in which the Government ought not to act, or to act only in a particular mode." 1 ANNALs of CoNc. 454 (1789). An excerpt is quoted by Justice Black in his dissent in Feldman v. United States, 322 U.S. 487, 501 (1944). 
ceded "exceptions" of this kind, do they not prove that the seemingly rigid First Amendment must be subjected to an emollient of "reasonableness"? Does not "reasonableness" pervade our entire juridical order? Certainly Justice Black has not contended that the sponsors of the First Amendment expected it to end civil actions for defamation. I understand he would freely grant the existence of this "exception."

He would probably go on to respond that civil remedies for defamation are not only consistent with but were considered by the founding libertarians as virtually essential to the maintenance of free speech and press. ${ }^{35}$ Exceptions of this type, existing and recognized in 1789, may be allowed as implicit in the First Amendment so long as, on re-examination in later epochs, they can be found still compatible with the main guarantees of the text. But-he would likely add-the operation of "reasonableness" factors was exhausted by exceptions of vintage 1789. Save only for these, the solemn text of the Amendment declares precisely what the American commonwealth has decided to call "reasonable." The decision having been made and declared once for all, there remains no further factor of "reasonableness" for the Congress or the Court to evaluate. It follows that what may have been a litigable question of reasonableness ante the First Amendment has been taken out of the judicial province post the Amendment. The judges' commissions simply do not authorize them to conduct inquiries within this area. If they re-open the closed question of reasonableness, they become chargeable with a usurpation.

Emphasis on the Hither Side of the 'Fences'. As has been noticed, Thomas Jefferson, writing to Noah Webster, classified the basic guarantees into "unceded portions of right" and "fences against wrong," and mentioned trial by jury, habeas corpus and free presses as examples of the "fences." Here he expressed quite fairly the libertarian mind of his time. In that era, the presswhich twentieth century thought tends to associate with other forms of free personal expression-was valued primarily for its function as political censor. ${ }^{36}$ Free presses were desired because they supplied the community with independent critics and censors of the government. With all their faults, they could nevertheless act like barriers against official tramps, trespassers and arsonists. This was the libertarian attitude that Jefferson espoused. As trial by jury and habeas corpus stood like fences to ward off official abuses, so too might the institution of press freedom. The fact that the governors were roving about on the far side of the fences was sufficient for him.

From the beginning, it has been evident that the "fences" themselves need unremitting attention and defense. In every generation they are gashed and rammed and undermined, often under a pretext of mending or modernizing them. As long as the fences continue to be appreciated only in a negative sense -as stockades against the forces on the far side instead of safeguards for the

35. Letter from Thomas Jefferson to James Madison, August 28, 1789. 7 THE WrITings of THOMAS Jefrerson 444 (Memorial ed. 1904).

36. See the proud claim on this score asserted in 1774 by the Continental Congress in its "Address to the People of Quebec." 1 Journals of Congress 58 (1777). 
values on the hither side-popular support for them will probably remain flabby, uninformed, and at best spasmodic. Our generation has had ample opportunity to observe that when an administration (like Franklin D. Roosevelt's or Dwight D. Eisenhower's) gains popular approval of its major objectives, the majority of Americans do not understand why they need feel concern about inherited rules of court procedure or other refinements of method. If, as libertarians insist, the First Amendment guarantees are the really vital ones, have not these been separated and distinguished from the list of procedural "fences"? Even should the fences sway and sag here and there, civil liberty does not inhere in them but in the "unceded portions of right." By such reasoning, people who feel deeply attached to the First Amendment may come to vilipend one or another provision in the Fifth, Sixth, or Eighth. Does the firstness of the First Amendment imply unimportance of the remainder?

Hugo Black has given his answer by turning attention to the inner side of the fences. We have understood what it is the fences are intended to exclude; he asks that we also appreciate what they are placed there to protect. In his view, the firstness of the First Amendment, far from diminishing the others, works to enhance their importance. He explains:

"The frrst of the ten amendments erected a Constitutional shelter for the people's liberties of religion, speech, press, and assembly. This amendmont reflects the faith that a good society is not static but advancing, and that the fullest possible interchange of ideas and beliefs is essential to attainment of this goal. The proponents of the First Amendment, committed to this faith, were determined that every American should possess an unrestrained freedom to express his views, however odious they might be to vested interests whose power they might challenge.

"But these men were not satisfied that the First Amendment would make this right sufficiently secure. As they well knew, history teaches that attempted exercises of the freedoms of religion, speech, press, and assembly have been the commonest occasions for oppression and persecution: Inevitably such persecutions have involved secret arrests, unlawful detentions, forced confessions, secret trials, and arbitrary punishments under oppressive laws. Therefore it is not surprising that the men behind the First Amendment also insisted upon the Fifth, Sixth, and Eighth Amendments, designed to protect all individuals against arbitrary punishment by definite procedural provisions guaranteeing fair public trials by juries. They sought by these provisions to assure that no individual could be punished except according to 'due process,' by which they certainly intended that no person could be punished except for a violation of definite and validly enacted laws of the land, and after a trial conducted in accordance with the specific procedural safeguards written in the Bill of Rights. If occasionally these safeguards worked to the advantage of an ordinary criminal, that was a price they were willing to pay for the freedom they cherished." "37

Here the Bill of Rights is revealed anew, in a fresh and original perspective. Suddenly the sections fall into their destined places, and a grand organic design stands out. The "fences," we see, do much more than channel, control

37. Feldman v. United States, 322 U.S. 487, 501-02 (1944) (dissenting opinion). 
or obstruct the currents of official action. They constitute the indispensable ministers and defenders of First Amendment freedom. Without them, the promises of free worship, speech and press become a mockery. In Justice Black's view, a legislative, executive or judicial mandate that impairs the guarantee of trial by jury or the privilege against self-incrimination puts every substantive liberty-including liberty of conscience-in jeopardy. If Americans are resolved to remain free, they will defend these fences as uncompromisingly as, in former times, citizens would defend their city walls.

The Ideal of an Edified Socicty. Now we have reached Justice Black's most creative contribution to the theory of the First Amendment. In the course of the great dialogue between Madison and Jefferson about the desirability of a bill of rights, neither correspondent took a naively exalted view of the democratic community. Madison saw in it the chief source of danger to civil liberty; Jefferson, while urging the people's case for guarantees against official oppression, was concerned more with safeguarding the elementary rights of individuals than with raising the level of the social group. ${ }^{38}$ Dwelling as he did in Paris and attending successive stages of the incipient French Revolution, he fully recognized the risks and evils of democracy. He referred to them in Horace's tidy phrase, "civium ardor prava jubentium" [frenzy of the citizens bidding what is wrong], and when he quoted Horace to Madison, it was not French but American behavior that was under consideration. In Jefferson's outlook of 1788-1790, a nation's claim to a declaration of rights could not be made to depend on the people's proving their discipline, wisdom or judgment. Since every government tended in some degree to encroach on basic liberties, all should be required to subscribe to solemn guarantees. Barricades in the Paris streets and Shays' Rebellion in Massachusetts were lively incidents, true. but any American who considered them impediments to a bill of rights must be either congenitally timorous or disingenuous. The focus ought to be placed and kept on the faults and wrongdoings of the governors.

It has been very difficult for First Amendment theory to move beyond this point. From the beginning, the Supreme Court has declined to determine questions of constitutionality unless the person seeking the decision could show he had legal standing to sue. When the rights in issue pertain to the First Amendment, the Court has expected to hear appeals from the individuals who were molested in their worship, or arrested for their speech or censored or impeded in their printing, or prevented from assembling to petition for

38. Of course, Jefferson was profoundly interested in popular education. Opening the Great Dialogue with Madison, he freely asserted he was "not a friend to a very energetic government" because it generally led to despotism; then by way of emphasis through contrast, he pointed to the sound judgment that could be expected from an informed people (at least so long as it retained an agricultural base). Ietter from Thomas Jefferson to James Madison, December 20, 1787. 6 THE Writings of Thoxas Jefrerson 391-92 (Memorial ed. 1904). But as will be seen, it remained for Justice Black to confer jural status on the community's First Amendment right to receive intelligence, to learn and to advance. 
redress of grievances. If a person's own rights had been injured, he could sue; otherwise not.

How, then, was the general community likely to come into view under this system? In only two ways: (a) in the course of denying a plea for some First Amendment freedom, the community might be pictured as susceptible to provocation, or seditious influence, or corruption; or (b) the community, represented by its duly constituted officials, might be before the court to argue for the validity of a law regulating or repressing some claimed First Amendment right. In either event, it would always be the individual or group of individuals on one side, speaking on behalf of freedom, and the community officially or tacitly on the other side, speaking at best for orderliness, quietness or unlittered streets, and at worst for persecution of unpopular cults and causes.

These circumstances, proper though they were for jurisdictional purposes, established a badly distorted social background for First Amendment litigations. Various laissez faire jurists proceeded to exploit the distortion. They took this extraneous datum, which the Court's own doctrines had manufactured, and purported to discover in it a pre-established, inflexible hierarchy of interests. Whoever might come before them as spokesman of First Amendment freedom was required to be an individual; ergo, his interest was to be labeled "an individual interest" of one kind or another. On the other hand, whoever might appear for the government was automatically dubbed the spokesman of "a public or social interest." Thus, in a typical opinion composed by a laisse faire judge-despite the parade of precedents and the show of reluctance and the business of weighing one interest against another-the whole question would be begged from the start and the result would be a foregone conclusion. Rare instances there have been when even such judges have allowed the so-called "individual interest" to prevail; but in these exceptional cases one generally finds that ulterior, corrupt motives impelling the prosecution were simply too obvious to be ignored. In sum, a purported "jurisprudence of interests," read anachronistically into the First Amendment, has become a familiar tool of laissez faire. It is quite analogous in its use to the purported "natural law" that stodgy minds of past eras were accustomed to read into the Due Process Clause. But while lawyers are generally able today to see through the old reactionary nomenclature of "natural law" immutables, a jargon of "weighing the interests" can still take them in..$^{39}$ The truth of the matter is that even if two conflicting or competing interests could somehow be weighed against each other, a judge might "fix" his own scale in half a dozen different ways before the alleged "weighing" began.

Justice Black has furnished the answer to this game of false balances. In the celebrated Marsh ${ }^{40}$ and Tucker ${ }^{41}$ opinions, among others, ${ }^{42}$ he presents the

39. See Judge Jerome Frank on these "quantifying" illusions, in The Lazvyer's Role in Modem Socicty: A Round Table, 4 J. Pus. L. 8,11 (1955).

40. Marsh v. Alabama, 326 U.S. 501 (1946).

41. Tucker v. Texas, 326 U.S. 517 (1946).

42. The rationale of the Marsh opinion had been adumbrated in Martin v. Struthers, 319 U.S. 141, 143 (1943). See also the dissenting opinions cited note 23 supra. 
libertarian ideal of an edified and advancing community. Where would we really find the principal danger to civil liberty in a republic? Not in the governors as governors, not in the governed as governed, but in the governed unequipped to function as governors. The chief enemies of republican freedom are mental sloth, conformity, bigotry, superstition, credulity, monopoly in the market of ideas, and utter, benighted ignorance. Relying as it does on the consent of the governed, representative government cannot succeed unless the community receives enough information to grasp public issues and make sensible decisions. As lights which may have been enough for the past do not meet the needs of the present, so present lights will not suffice for the more extensive and complex problems of the future. Heretofore public enlightenment may have been only a manifest desideratum; today it constitutes an imperative necessity. The First Amendment, says Justice Black, "reflects the faith that a good society is not static but advancing, and that the fullest possible interchange of ideas and beliefs is essential to attainment of this goal." 13

If, therefore, judges should still insist on using the nomenclature of "interests," what higher public interest is there than enlightenment of the electors, and what higher social interest than the intellectual advancement of the community? Not alone the speaker, missionary, writer or printer, has a stake in the First Amendment ; the whole conglomerate mass of the community andience is involved,44 including those who are almost sure they will never wish to speal: and those who are completely sure they do not wish to listen. Under Black's doctrine, no one is required to listen, but even a unanimous unwillingness to listen does not justify repression, for an advancing society must be free to revise its judgment on this score as well as on others. The audience has the indefinitely continuing right to be exposed to an ideological variety ; it will not be heard at any one period of time to renounce exercising the right in other, future periods.

Justice Black's ideal carries an ambitious compliment for the democratic audience. He assumes, in effect, that if given access to the various facts and contentions, the members of the audience are generally rational enough to identify, and well-intentioned enough to choose the better, wiser, more beneficial of alternative courses. Or at least, that though this method of political decision may be faulty, any other method would prove disastrously worse. Since ancient days when the stubborn backsliding Israelites made life difficult for Moses, no nation has ever complied satisfactorily with the ordinances of its finest preceptors; nor, for that matter, has any of the preceptors lived with perfect consistency on the plane of his own teachings. Yet considerations lilse these need not cloud a sincere democratic faith. They only demonstrate that social progress involves continual striving and that men strive for what lies

43. Feldman v. United States, 322 U.S. 487, 501 (1944) (dissenting opinion).

44. United Nations reports illustrate the extraordinary value of this approach whut applied to international communication of intelligence. See the Universal Declaration of Human Rights art. 19, adopted by the General Assembly of the United Nations a": December 10, 1948. 6 U.N. BuLL. 6 (1949). 
beyond them rather than for what they already possess. In Justice Black's hands, the Bill of Rights is directed toward the values that lie beyond. He reads it as a people's charter of edification, and postulates the kind of national community whose practices would do daily honor to the First Amendment. It would be an American community not unworthy of Madison's and Jefferson's best aspirations.

The practical fulfillment requires certain cultivated traits of mind and character. They are the traits Jefferson specified to Madison when he recommended looking to the judges to enforce a bill of rights. He cited the names of Pendleton, Blair and Wythe. The consummate qualities they exemplified in their generation, Hugo Black exemplifies in ours. IVhen, after mentioning those great figures, Jefferson went on to quote a phrase out of Horace, he probably intended to invoke the remainder of the strophe. It sings of justice and integrity:

Iustum et tenacem propositi virum Non civium ardor prava iubentium Non vultus instantis tyranni Mente quatit solida, neque Auster ....
The just man firm of purpose turns aside Neither for fury of the mob in power, Nor in the presence of the tyrant's pride; Nor can the stormy South wind make him cower ....45

It is these classic republican virtues that will ultimately maintain the firstness of the First Amendment. 1947).

45. Horace's Odes, bk. III, ode iii, in The Odes of Horace 82 (Dunsany transl.

To the Justices of the Supreme Court, the South wind may feel unusually stormy these days. But informed Americans understand that worthier things than wind come from the South; and as for the uninformed, they can profit by noting that Alabama produced Hugo L. Black. 